Medisin og kunst

\title{
Det vonde lyset - våkenhet og melankoli hos maleren Edward Hopper
}

Depresjon var et tilbakevendende tema i den amerikanske maleren Edward Hoppers (1882-1967) liv. Hopper er kjent som en av dem som i nyere tid mest overbevisende visuelt har formidlet melankolien. I artikkelen er hans originale malerkunst bakgrunn for en refleksjon om søvn, våkenhet og melankoli. Hopper bringer marerittene inn i lyset og dagen og søvnløsheten inn i den avslørende morgensolen.
Edward Hoppers skikkelser er ensomme. Hans maleri Hotel room fra 1931 er ikonografisk for hans livsverk. Vi ser en delvis avkledd kvinne alene i et trangt hotellrom. Ansiktet er bokstavelig talt lagt i skygger. Hun leser i en rutebok, og skal altså videre. Bagasjen står uåpnet, og hun sitter på sengen i stedet for å ligge på den. Har hun sovet, eller har hun ikke fått sove? Det er et skremmende morgenlys i bildet.

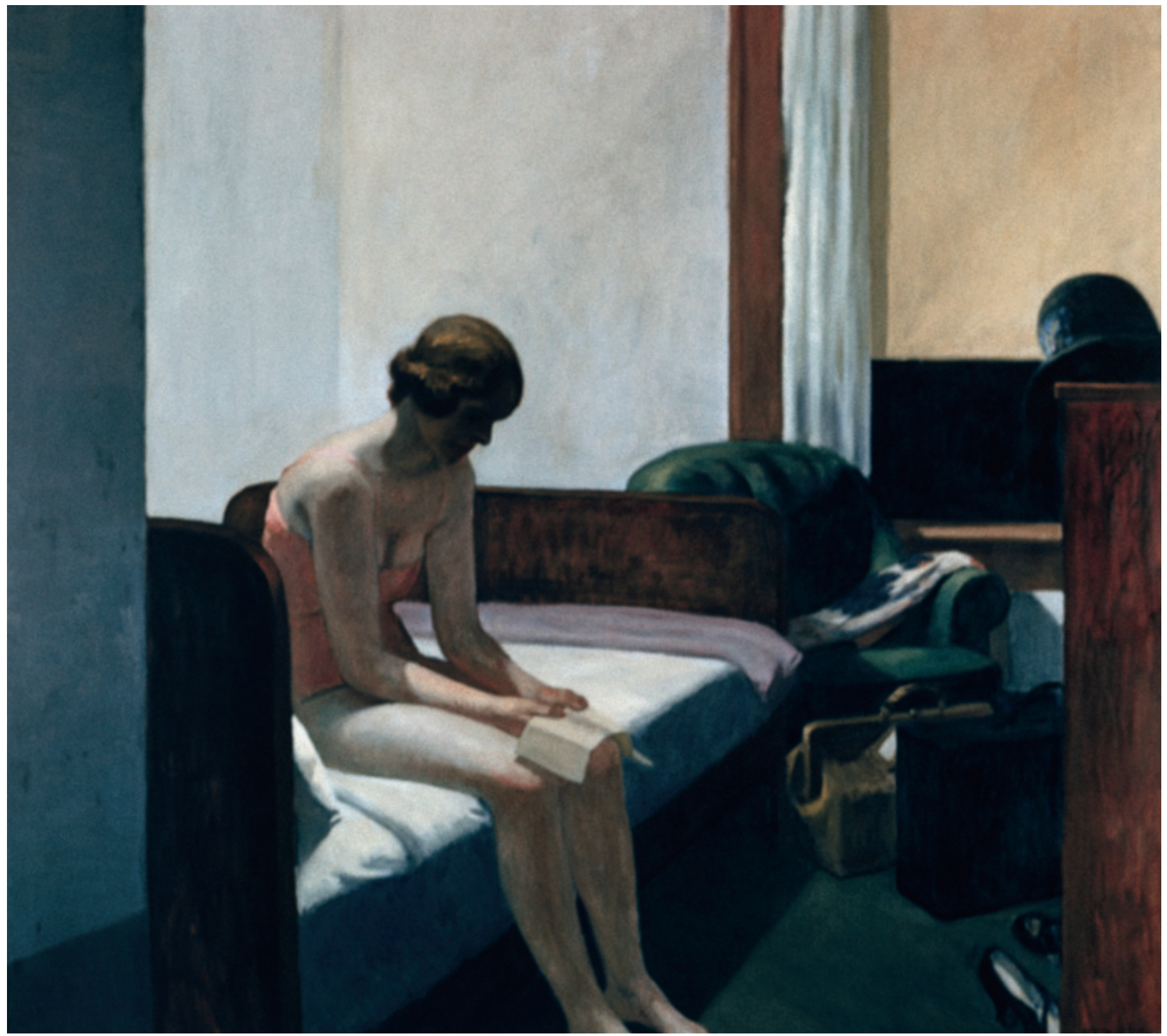


Når det er to eller flere til stede i Hoppers bilder, er de som frakoblet hverandre. De ser ikke på hverandre, men forbi eller vekk. Kommunikasjon kan synes vanskelig. To slike par er avbildet i maleriene Summer in the city (1949) og Excursion into philosophy (1959). I begge disse bildene, som i tema, komposisjon og emosjon er svært like, er det slik at den ene sover mens den andre er plagsomt våken. Den ene ligger i sengen mens - igjen - den andre sitter på den. At de er par, betyr ikke at de får noen form for trøst fra intimiteten, snare tvert imot. Partneren ser ut til å sove tungt, som om vedkommende ikke vet, forstår eller bryr seg. Den britiske kunsthistorikeren Margaret Iversen skriver at tilstanden til de to våkne er mer enn en postkoital tristesse eller frustrasjonen over et dårlig forhold (1). De er som fanget $i$ en eksistensiell pine. De stirrer begge mot et rektangel av sollys på gulvet, men ser først og fremst ut som om de stirrer innover i sine egne bekymringer. Og det samme gjelder kvinnen i Hotel room. Ser hun egentlig i ruteboken?

\section{Melankoliens kropp}

Den sittende posisjonen til de tre våkne gir sterke assosiasjoner til Albrecht Dürers (1471-1528) Melencholia I fra 1514 og for øvrig til utallige avbildninger av grublere, tenkere og deprimerte - den samme foroverlente stillingen, ubevegelig posisjon, med bøyd nakke, som om et tungt hode med tunge tanker trekker nedover. Det er som om dette er den melankolske kroppsposisjonen sui generis. Den viser til en kroppsmetaforikk hvor sinn og kropp blir ett: Den følelsesmessig tyngede kjenner seg kroppslig tung. Den som lider, blir bøyd av livet. Den sveitsiske legen og litteraturforskeren Jean Starobinski (f. 1920) gjør et poeng ut av at de franske verbene penser (tenke) og pencher (bøye) har samme språklige opphav (2).

De to våkne virker handlingslammet, slik Dürers melankoliskikkelse har vinger, men ikke ser ut til å være i stand til å fly. Det er generelt lite handling i Hoppers malerier. Hans skikkelser er avventende og ikke-agerende. Og når det er handling, er det gjerne stillesittende lesing det er snakk om. Hustruen Jo skrev i en dagbok om Excursion into philosophy at «den åpne boken er Platon, gjenlest for sent» (1). Møtet med teksten fører til grubling. Kanskje det betyr «for sent i livet», fordi man som Hopper selv blir gammel, eller at Platons tekst har fått den grublende leseren til (for sent) å innse at han har latt seg styre av det fysiske, materielle og seksuelle i stedet for ideenes ideelle og opphøyede verden.

\section{Det avslørende lyset}

Mange av Hoppers bilder viser kvelden eller natten, slik som hans mest kjente Nighthawks fra 1942. Natten og mørket kan gjøre oss sårbare. Og det er tiden da marene rir oss - her fremstilt i det kjente maleriet MareDen lumske marekatten sitter oppå den hvitkledde kvinnen, og en hest med lystne, glødende øyne begjærer henne. Mørket er også en sterk metafor for nedstemthet, slik Julia Kristeva (f. 1941) beskriver det i boken Svart sol. Depresjon og melankoli (3). Når solen er svart, blir alt svart.

Men det opplyste har også sin «horror». Hopper bringer nedstemtheten og angsten til dagen og den opplyste moderniteten. Han bruker lyset mesterlig til å formidle stemninger og gir det opplyste en tvetydighet. Solen er livgivende og nærende, men den sterke morgensolen kan også være plagsomt påtrengende fordi den er avslørende. I det altfor sterke lyset avdekkes symbolsk våre liv for oss - livet med alle sine tilkortkommenheter, fadeser, bekymringer og mangler. Lyset holder oss våkne.

En tradisjonell forståelse av det melankolske handler om ubehaget som er skjult i et mørke - hemmeligheter og det ubevisste sjeleliv - og som hjemsøker oss. En mer moderne forståelse handler om at vi ris, ikke av marer som symboler for det skjulte, men av det åpne og alt det vi vet om oss selv. Det er ikke lenger så mye å skjule, og vi vet nok.

Edward Hoppers bilder er meget vakre og meget urovekkende. Med sine sterke farger, bruken av lys og skygge og sine presise komposisjoner gir han oss den stille desperasjonen til skikkelsene i bildene. Det er noe svært uhyggelig over mennesker som mangler evnen til tilknytning og trekker seg tilbake i sin egen melankolske kvernende og søvnfrarøvende grubling. I Fuselis bilde av marerittet kommer det skremmende utenfra, hos Hopper kommer det innenfra. rittet (1781) av Henry Fuseli (1741-1825).

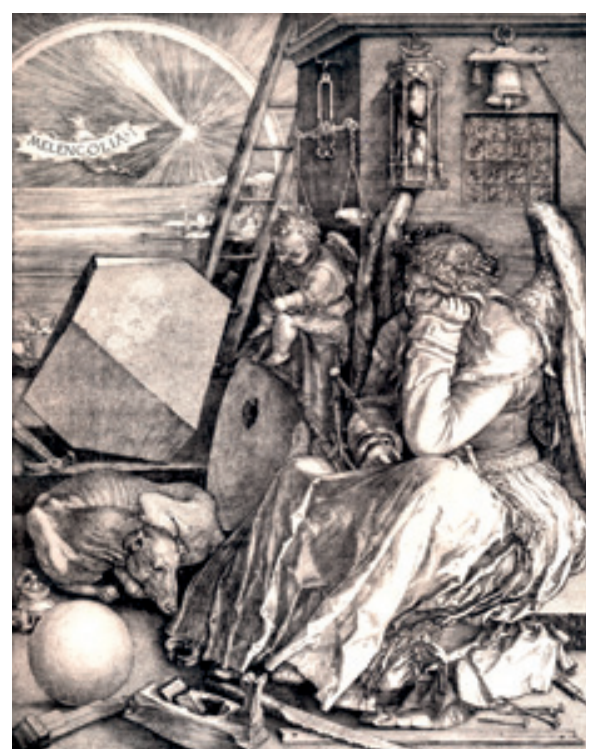

Melencholia I (1514). Radering. Albrecht Dürer. Foto (C) Science Photo Library/GV-Press/NordicPhotos

\section{Finn Skårderud}

finns@online.no

Avdeling for helse- og sosialfag

Høgskolen i Lillehammer

2626 Lillehammer

Oppgitte interessekonflikter: Ingen

\section{Litteratur}

1. Iversen M. Hopper's melancholic gaze. I: Wagstaf S, red. Edward Hopper. London: Tate Publishing. 2004: $52-65$

2. Starobinski J. Fra kroppsfølelsens historie. Oslo: Cappelen, 1992

3. Kristeva J. Svart sol. Depresjon og melankoli. Oslo: Pax, 1994

Manuskriptet ble mottatt 2.8. 2009 og godkjent 27.8. 2009. Medisinsk redaktør Anne Gitte Hertzberg.

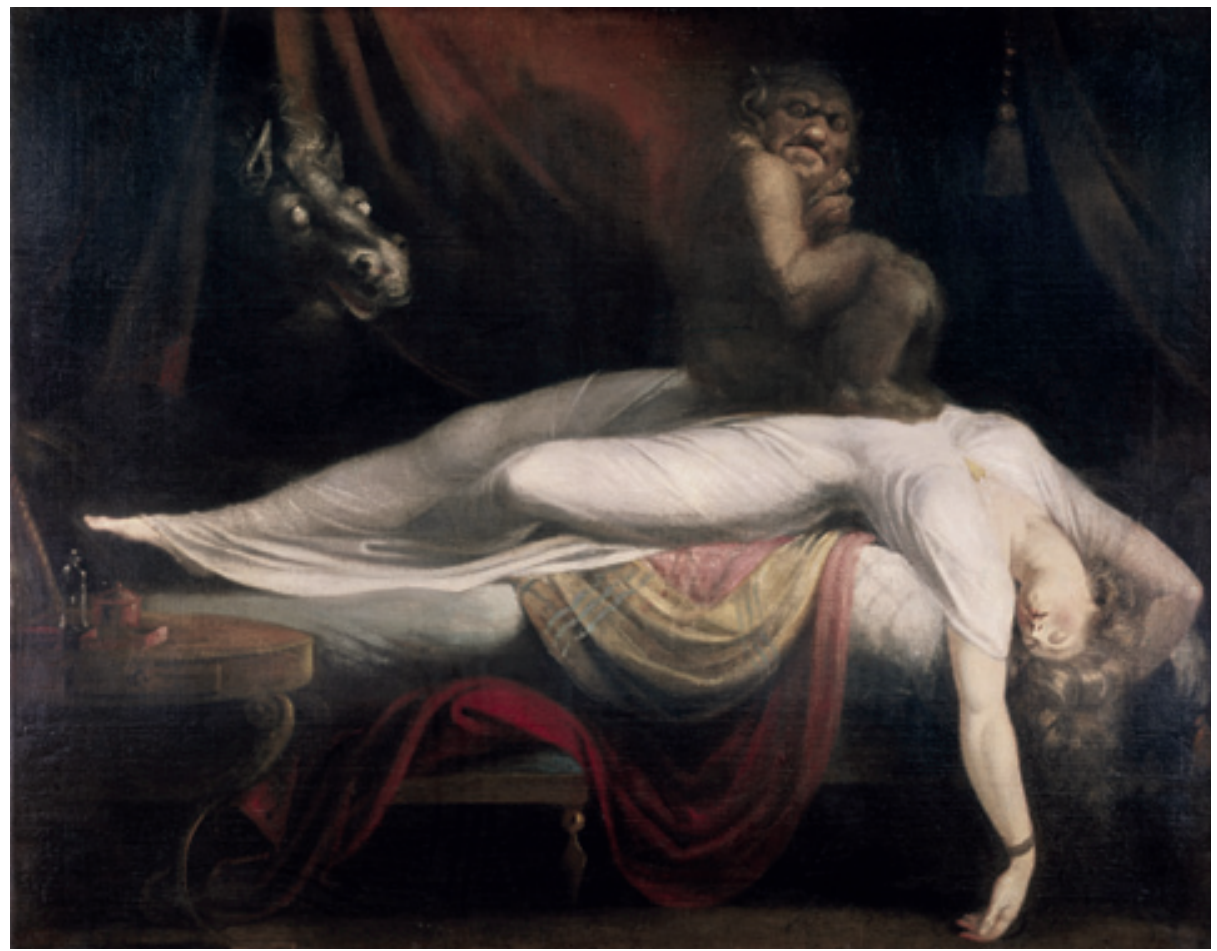

Marerittet (1781). Olje på lerret. Henry Fuseli. Foto (c) SuperStock/GV-Press/NordicPhotos 